\title{
Traditional Intricate Paper Cutting Techniques of Southern Thailand: Background, Beliefs, and Cultural Animation of Thai Buddhist Culture
}

\author{
Pannee Virunanont (พรรณี วิรุณานนท์) \\ Ph.D., Assistant Professor, Communication Design Department, \\ School of Fine and Applied Arts, Bangkok University, Bangkok, Thailand \\ pannee.v@bu.ac.th
}

\begin{abstract}
Intricate paper cutting of Southern Thailand is a traditional folk art, which is passed down from one generation to another. However, there are no detailed studies or records of the historical backgrounds, beliefs, and cultural animation of Thai-Buddhist culture in Southern Thailand concerning this folk art. This study, therefore, aims to examine this art form in Songkhla and Nakhon Sri Thammarat provinces, which have their own cultural identities. The goal is to register this art form as a part of cultural heritage. The compilation of vital data includes (1) paper characteristics, (2) paper engraving methods, (3) colours, (4) instruments, (5) pattern designing, (6) purposes of the arts, (7) origins and history, and (8) knowledge of transferring methods. The findings reveal the origins of the beliefs and Buddhist faith of the community. The intricate paper cutting techniques are still maintained in the form of decorations found at auspicious events, festivals, and cultural ceremonies in every region of Thailand. The techniques of this art form are in decline but its use still prevails in community life, remaining favourites at auspicious festivities and cultural events for the sake of conserving distinct identities.
\end{abstract}

\section{Keywords}

beliefs - cultural animation - Southern Thai - intricate paper cutting 
บทคัดย่อ

งานตอกกระดาษปักษ์ ใต้: ความเป็นมา ความเชื่อ และการสืบสานวัฒนธรรมไทย-พุทธ

งานตอกกระดาษปักษ์ใต้เป็นงานช่างฝีมือดั้งเดิม ประเภทศิลปกรรมพื้นบ้านที่สืบทอดจากรุ่น สู่รู่น อย่างไรก็ตาม เมื่อกล่าวถึงความเป็นมา ความเชื่อ และการสืบสานวัฒนธรรมไทย-พุทธ ในพื้นที่ภาคใต้ ในส่วนที่เกี่ยวกับศิลปกรรมพื้นบ้านชนิดนี้ ปัจจุบันยังไม่มีงานวิจัยใดศึกษาไว้อย่าง ละเอียด หรือบันทึกไว้สำหรับเป็นแหล่งค้นคว้าเพื่ออ้างอิง งานวิจัยนี้จึงมีจุดมุ่งหมายเพื่อศึกษา ศิลปะประเภทนี้ ที่จังหวัดสงขลาและจังหวัดนครศรีธรรมราช ซึ่งมีความโดดเด่นและมีเอกลักษณ์ ในศิลปะตอกกระดาษ ทั้งนี้เป้าหมายของงานวิจัยนี้คือเพื่อให้ศิลปะนี้ได้รับการจดทะเบียนขึ้นเป็น มรดกภูมิปัญญาทางวัฒนธรรม ในด้านข้อมูล เนื้อหาสำคัญที่รวบรวม คือ (1) ลักษณะกระดาษ (2) วิธีการตอกกระดาษ (3) สี (4) อุปกรณ์ที่ใช้ (5) การออกแบบลวดลาย (6) วัตถุประสงค์การใช้งาน (7) ประวัติความเป็นมา และ $(8)$ วิธีการถ่ายทอด ข้อค้นพบชี้ให้ทราบถึงที่มาของความเชื่อและการ นับถือศาสนาพุทธของชาวชุมชน และมีการนำงานตอกกระดาษมาประดับในงานบุญ งานเทศกาล และงานประเพณีของทุกภูมิภาค แม้จะพบว่าเทคนิคของศิลปะนี้จะเสื่อมถอยลง แต่ก็มีการนำ ศิลปะนี้ไปใช้อย่างแพร่หลายในวิถีชีวิตของชุมชน และยังคงมีความนิยมสูงโดยเฉพาะในงานมงคล หรือกิจกรรมทางวัฒนธรรมในฐานะผู้ช่วยอนุรักษ์อัตลักษณ์ที่โดดเด่นของไทย

\section{1 \\ Introduction $^{1}$}

Traditional intricate paper cutting techniques are used to decorate places and objects. Thailand considers these techniques to be part of its cultural heritage. They can be categorised into two types according to their purpose. The first type encompasses decorations used at auspicious events and the second, funerary events. The auspicious decorations serve the purpose of creating atmosphere. They act as an informative medium, rousing interest from the public by letting them know that a merit making or auspicious event is about to take place. These decorations are also linked to the thoughts of people who believe in angels and sacred objects. These decorative designs are made for angels to behold and acknowledge. Upon knowing about these events, the angels will bestow good fortune upon the event organiser. The paper used for decoration is cut into Lai Thai (Thai patterns), traditional Thai Art, or the 12 animals of the zodiac. The drawing or engraving forms are a reflection of Thai craftsmen's wisdom. The paper patterns are used to decorate flags and are hung with Mahot

1 The term "cultural animation" in the title was originally coined by Polish cultural theorist, Grzegorz Godlewski, as "identification, activation, dynamisation of a particular sphere of cultural experience." In this paper it refers to Thai Buddhists' passing down knowledge of intricate paper cutting techniques of Southern Thailand from one generation to another. 
bunches (Thai traditional paper mobiles). The second type, funerary decorations, are used in solemn events. They are decorative patterns engraved onto mortuary coffins holding the deceased. These mortuary patterns are of the Lai Thai style and are exquisitely decorated on the coffins. They serve to add beauty and value to the coffins while the religious practice is in procession.

There are techniques developed from intricately cutting and shaping gold and silver aluminium foil into prominent Lai Thai (Thai patterns) ${ }^{2}$ such as Lai Lukfak Kampu Bai Thet, Lai Pracamyam Kampu, Lai Bua Khop, Lai Khanap, and Lai Krui Choeng designs. I investigated the origins of Thailand's traditional intricate paper cutting techniques by conducting documentary research and collecting data from primary sources. It was found that this technique is a traditional craft categorised under traditional handicrafts, which is in turn a type of sculpture craftsmanship (Department of Cultural Promotion, Ministry of Culture 2014).

Intricate paper cutting artisans reside in all regions of the country and are involved in community cultural and festive events. Their crafts are passed down from one generation to another. Their traditional skills are unique and accord with their local and individual styles. Artisans of the northern region use intricate paper cuttings to adorn palaces, coffins, or pavilions pertaining to Lanna culture. The materials used include gold and silver aluminium foil or coloured paper (Phonphenphiphat 2003). Artisans of the northeastern region use intricate paper cuttings to decorate auspicious events that pertain to cultural customs, such as the Hiid Sib Song Khlong Sib Sii (Heat twelve traditions Kong fourteenth) festivals of the Isaan region. This event is an amalgam of three beliefs: Buddhism, Hinduism, and animism (Raksutthi 2012). Artisans of the central region use intricate paper cuttings to adorn funeral pyres in the Sanam Luang ground, ${ }^{3}$ royal funerary pyres, pavilions, and edifices in royal ceremonies. Artisans of the southern region use the same material to create patterns for decorating both coffins and Chak Phra (Buddha Pulling) vehicles, which are used in the Chak Phra (Buddha Pulling) festival after the monsoon season that symbolizes Buddha returning to Earth. They can be found on both the eastern and Andaman coasts of Southern Thailand. The former includes the provinces of Songkhla and Nakhon Sri Thammarat. The latter includes the

2 See Figures 6 to 20.

3 The Sanam Luang ground is in the Phra Nakhnon district. Sprawled in front of the Wat Phra Kaew and the Grand Palace, this large field associates its name with important celebrations in Thailand. It serves as the venue for national celebrations, including the King's Birthday, the Royal Ploughing Ceremony, the New Year Festival, the Kite Flying Competitions, etc. Since the reign of Rama I, the park has also served as the site for conducting many royal cremation ceremonies. 
province of Trang, where the patterns appear to be influenced by Chinese artistic customs. These influences can be observed in colour usage and the rigidity of patterning (Virunanont 2015).

This traditional intricate paper cutting craft is classified as one of the Ten Crafts of Thailand ${ }^{4}$ and is named Thong Yon Paper Craft. Nowadays, this craft is prominent within the southern region as artisans use it to decorate the Saat Duean Sib (Festival of the Tenth Lunar Month), the Phanom Phra Boat in the Chak Phra festival both on water and on land, and funerary ceremonies such as adornments for coffins and funeral pyres of Thai Buddhists residing in the four provinces of Southern Thailand (Nakhon Sri Thammarat Province Cultural Office 2006).

I observed that intricate paper cutting techniques are still maintained in the forms of decorations found at auspicious events, festivals, and cultural ceremonies of every region in Thailand. These techniques are on the decline but still prevail in community life, remaining favourites at auspicious festivities and cultural events for the sake of conserving distinct identities. Nonetheless, there have been no detailed studies or records of the historical background, beliefs, and cultural animation of knowledge transfer of Thai-Buddhist culture in Southern Thailand for the purposes of research and reference.

The main purpose of this research is to study, survey, gather and collect information on all aspects of traditional intricate paper cutting techniques of Southern Thailand, to be submitted to Thailand's National Inventory of Intangible Cultural Heritage as traditional folk art craftsmanship. It is supported by the Department of Cultural Promotion, Ministry of Culture.

\section{Research Methodology and Data Collection}

This study is a qualitative research that emphasizes primary resources and utilizes the principles of Grounded Theory that sociologists Barney G. Glaser and Anselm L. Strauss developed in 1967. They proposed that the principle of Grounded Theory be utilized as a method of analysis for qualitative research, wherein one primarily receives the information from the most importance sources and systematically accumulates research related information (Glaser and Strauss 2010). Grounded Theory is relevant to the research procedure, method, and process (Glaser and Strauss 2010) and Strauss \& Corbin (1990,

4 The Ten Crafts of Thailand are: 1. Drawing 2. Sculpture 3. Carving 4. Engraving 5. Moulding 6. Turning 7. Modelling 8. Lacquering 9. Metal Beating and 10. Plastering. Thai paper cutting is included in carving. 
1998, as cited in Glaser and Strauss 2010). The concept of Grounded Theory is the process of using the information to learn how people give meaning to circumstances or their actions, through the analysis process of categorizing, generating codes, and the study of social phenomena. The logic of Grounded Theory suggests that the method of data-gathering is equivalent to the theoretical development (Charmaz 2006). Therefore Grounded Theory is Process Theory (Sarrattana 2013) and "the mythology development of Grounded Theory is the research mythology emphasized on the learning of social phenomenon by following the understanding principle of value, thought, belief or perspective from people in society" (Havanon, Jeradechakul, and Pudthaisong 2007).

This study collected data via participation and observation, where the researcher observed and participated in certain activities, such as practising how to engrave on paper or learning about cutting procedures under the guidance of the master artisan. Furthermore, focus group discussions were held with nine groups of expert artisans. Small group discussions were simultaneously held with artisans as well. This was done to validate data accuracy via triangulation checking; this ensured that the collected data on artisanal knowledge focused on paper cuttings. Similarities and differences were expected, depending on whether the artisans were disciples of the same master or shared similar fundamental beliefs. Artisans who practised under one master or had similar fundamental beliefs should not differ much in their cutting techniques and other details. In addition, in-depth interviews were conducted with the artisans who participated in the group discussions (both masters and students). That data was validated by data collected from the small group discussions, focus group discussions, and participation observations.

The most important aspect of qualitative research is quality verification by Triangulation Check-Clarify. Chantavanich $(2009,32)$ said that the principle of Triangulation Check-Clarify is not to trust the first data source. Researchers need to explore the possibility of alternative data sources. Therefore, this study verified the data by checking with other data sources (data triangulation), alternating between people, time, and places that provided the information. The research was conducted by the following steps: (1) collecting the basic information by participatory observation of the community, studying the historical origins, and inquiring about the traditional intricate paper cutting techniques process; (2) gathering information through in-depth interviews with artisans on their knowledge of the history, identity, procedure, tools, and pattern designs; (3) gathering information from small group discussions about the approach to preserving the art form's artistically distinctive characteristics, which led to an analysis of the beliefs, religion, and ethnography; and (4) 
verifying and correcting the information through in-depth interviews with the local philosophers, artisans, teachers, sub-district headmen, and village leaders in order to authenticate the information about the history, pattern designs, and distinctive characteristics. This information collecting procedure supplied this study with knowledge of the techniques, history, procedure, tools, pattern design, culture, beliefs, and knowledge transfer system of the Southern Thailand traditional intricate paper cutting craft.

Data was collected from two southern provinces - Songkhla and Nakhon Sri Thammarat, where paper cuttings are most densely concentrated. The main sources of knowledge were nine artisan masters. Pictures were also taken and, at subsequent meetings, verified by knowledgeable artisans. These meetings included local people or art teachers and other affiliated people such as community leaders, village heads, youth groups, and villagers. The meetings determined the credibility of the collected data. Missing or inaccurate knowledge was amended according to the actual physical and oral database existing in the community. The data was studied from 30 December 2014 to 30 December 2015. The data from Songkhla was collected from 24 February 2015 to 11 October 2015. The data from Nakhon Sri Thammarat was collected from 10 September 2015 to 30 November 2015. Archival research was conducted by consulting annals, diaries, reports, and other documents.

\section{3}

Background, Beliefs and Evolution of Southern Thailand

\subsection{Cultural and Ethnic Background}

Most areas in the southern region of Thailand are adjacent to the sea and many cities are seaports. (see map in figure 1) These two factors enabled easy access to international relations. Many countries such as Malayu, Java, China, India, Saudi Arabia, as well as Western nations, have had historical contacts with Thailand. The Chinese, for example, traded with Thais from the $11^{\text {th }}$ century to the $5^{\text {th }}$ century BC in items including pearls, glassware, perfume, gems, and rhinoceros horns. It is possible that trade with the Chinese is linked to the importing of gold foil paper into Thailand. Later, the Indians came to Thailand with their religious beliefs. Their Hindu influence can be found in Thai arts, such as bronze sculptures of Bodhisattva in various postures like Nang Panya Baramee (Virtue goddess) and Nang Doen (Walking goddess) and the Ramayana literature, beliefs, traditions, and legal system. Another intriguing aspect of Southern Thai culture is the influx of Persians and Arabians into the region from the $7^{\text {th }}$ century to the $10^{\text {th }}$ century AD. These two nations originally came to trade spices and spread Islam to the island of Sumatra, their influence 


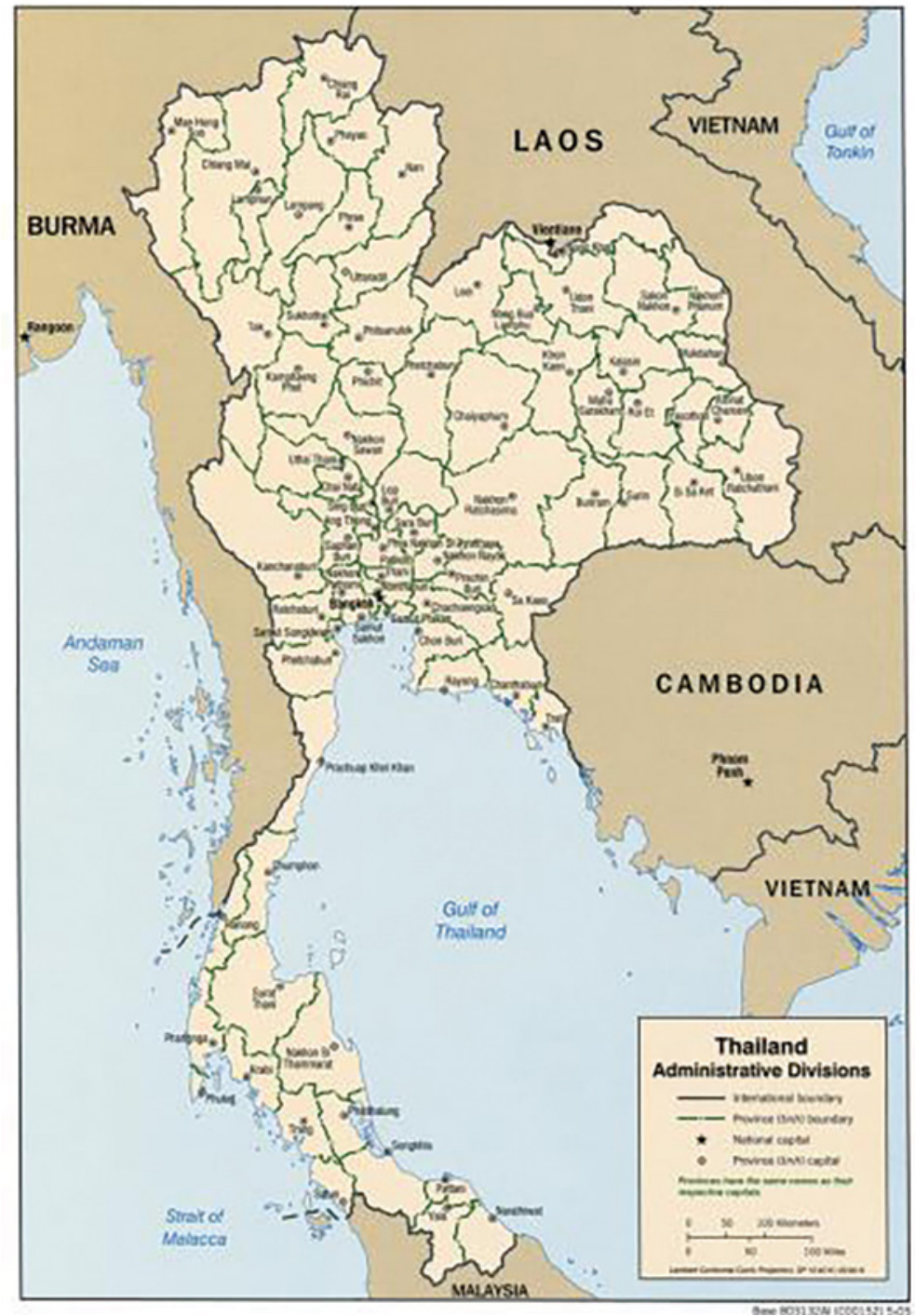

FIGURE 1 Thailand map

SOURCE: THAILAND MAP (N.D.)

resulting in the expansion of Islam to the Malay Peninsula. This belief spread northwards to Southern Thailand and southwards to Indonesia. By the $15^{\text {th }}$ century AD, certain indigenous people of Southern Thailand started to convert to Islam.

In addition to Muslim and Buddhist Thais residing in the area, there are people with distinct beliefs and customs who belong to other ethnic groups. 
One such group of native people is called the Chao Nam or Chao Le (Sea folk), who still reside along the coasts of Takua Paa district in Phang Nga province, Rawai Beach, and Sire Island of Phuket province, and the islands of Satul province. Today, they call themselves Chao Thai Mai (The New Thais) and maintain the profession of fishing. Another group of indigenous people are the Orang Asli (Sakai) or $\mathrm{Ngo} \mathrm{Pa}$, natives of the Palian district in Trang province and the Bannang Sata and Betong districts of Yala province. They believe in the supernatural and are superstitious about fortunes, spirits and ghosts, health, symbols and dreams.

Customs and beliefs are reflected in the attire of the various ethnic groups of Southern Thailand. For example, Thais of Chinese descent dress according to Chinese customs, Thais of Malay descent dress similarly to Malaysians and Thai Buddhists conform to native Buddhist customs. On the other hand, handicraft products such as Ko Yo fabric, Phum Riang silk, Mueang Nakhon woven fabric, Batik fabric, jewelry, silverware, gold ornaments, brass and nielloware, Yan Liphao wickerwork and shell ornaments, are exclusive to indigenous Thais (The Southern Region 2004).

Hence, Southern Thai folk culture is considered a cultural blend because geography, history, multiple religions, and local traditions have influenced the culture of this region. In other words, this is an aspect of cultural heritage worthy of conservation (Chumphengphan 2005). Communities of Southern Thailand maintain beliefs which are predominantly Buddhist. (Nakhon Sri Thammarat Office. 2009) For instance, southern people believe in shamans, in the aspect of Buddha's virtue, sacred objects in rituals, and spirits. As for superstition, these beliefs originated in Hinduism, and have been incorporated into the ways of life of certain community members. The knowledge transfer of these beliefs is conducted in temples, with monks acting as the chief performers of this act.

\subsection{Notable Festivals Related to Buddhist \& Hindu Beliefs \\ 3.2.1 Chak Phra \& Tak Baat Tewo}

LaakPhra (or ChakPhra) (Buddha Pulling) is an important festival that reflects the Thai-Buddhist culture of Southern Thailand. This festival is held at the end of the Buddhist Lent, which falls on the first day of the waning moon in October. According to the Historical Life of Lord Buddha, this day was the very day when Lord Buddha descended from Heaven to Earth by the Gold and Silver Staircase after preaching to his mother for an entire Lent at Dusit Heaven. On the 15th day of the waning moon in October, he descended further by the Three Silver Staircases to the gates of Sangkassa city. When he reached the gates of the city, it was the morning of the gth day of the waning moon in October, 
the Buddhist Lent. Buddhists who heard about the descent of Lord Buddha welcomed him with offerings of food, flowers, candles and incense at the event of which is named the Tak Baat Tewo custom. During this event, many people were unable to reach Lord Buddha to offer food due to the density of the crowd surrounding him. This did not dilute their devout faith and they thought of a method to convey food to Lord Buddha by making desserts wrapped in pandanus leaves. This leaf-wrapped dessert was thrown over multitudes of people as offerings. This dessert is named Khanom Tom, Ho Tom, or Ho Pad and is the specialty of this festival.

\subsubsection{Songkran}

Songkran Festival is the traditional Thai New Year which is on 13th April every year. Thai Buddhists give alms to Buddhist monks in the morning of the New Year. In traditional beliefs, symbolism is a key ingredient of the ceremony and includes the water representing the meaning of summer. People pour water to refresh and ask for a blessing from their parents and grandparents, as well as to show gratitude to them.

\subsubsection{Saat Duean Sib}

The Saat Duean Sib (Festival of the Tenth Lunar Month) is a traditional merit making event of the Southern people of Thailand, especially in Nakhon Sri Thammarat. It is influenced by the Hindu ritual of Peta Phlee. Its aim is to be a charitable dedication for the souls of ancestors that is held on the ist lunar day to the $15^{\text {th }}$ lunar month of the tenth lunar month every year.

Geographical Locations, Beliefs and Intricate Paper Cutting Pattern Differences: Songkhla and Nakhon Sri Thammarat

Art is prominently distinctive according to its ethnicity (Leesuwan 2000). In addition, the artistic designs in handicrafts, drawings, performances, and so on, are shaped by the absorption of events that surround humans. These events include local natural resources, geographical features, and beliefs pertaining to the supernatural, such as ghosts and spirits. Studies on the technical aspect of Thai visual arts were conducted in the southern region, focusing on the eastern coast along the Gulf of Thailand. Temples in the provinces of Chumphon, Surat Thani, Nakhon Sri Thammarat, Phattalung, Songkhla, Narathiwat, and Pattani demonstrate that the visual arts of Southern Thailand act as a medium for exhibiting Buddhist faith and beliefs. This portrayal incorporates multiple methods of intermixing the artistic techniques of royal artisans, Chinese 
culture, Western culture, Hindu culture, Javanese culture, and Islamic culture (Thuree 2016).

Songkhla province lies on the eastern coast of the lower part of Southern Thailand. The province's north is a peninsula that extends southwards, composed mostly of lowlands. To the east, the province is composed of coastal plains, with riverbanks suitable for docking ships, while the south and west are composed of mountains and plateaux. In this province, there exist ancient communities and cities. Historical sites, artefacts, cultural traditions, folk amusements, and folk arts are also found here and are considered Songkhla's cultural heritage. In ancient times, Songkhla was the centre of the Chitu kingdom, which was influenced by Indian culture for at least seven centuries. Later on, it became a large province of Siam during the Thonburi and early Rattanakosin eras. Today, the most popular religion is Buddhism, followed by Islam, Christianity, and Hinduism respectively. According to Sirirak (2009) there were 401 Buddhist temples, 95 monasteries, 367 mosques, and 16 churches in the province. The types of cultural arts found in Songkhla can be classified into three categories: paintings, architecture, and handicrafts. Unique paintings can be found in the murals of the following temples: Machima Wasawora Wihaan Temple, Suwan Khiri Temple, Pho Pathamawat Temple, Ja Thing Phra Temple, Khu Tao Temple, and Pha Kho Temple. Chinese architecture can be observed in residential buildings, shrine buildings, cemeteries, temples, and local artisan products.

There are three Songkhla festivities worthy of mention in this article. The first is the Songkran festival. The second is the Chak Phra (Buddha Pulling) and Tak Baat Tewo festivals, where processions of boats holding Buddha images of various temples can be seen. The third is the Wan Saat (Ching Pred) festival, where people make merit to deceased house members.

\section{Nakhon Sri Thammarat Province}

Nakhon Sri Thammarat province is situated in the centre of Southern Thailand, adjacent to and north of Songkhla. The Nakhon Sri Thammarat mountain range is located along the peninsula. The province's geography is divided into three parts: (1) the central part, which is a mountain range; (2) the eastern part, which consists of coastal plains; and (3) the western part, which consists of 
plains. Important rituals of Nakhon Sri Thammarat follow the Langkawong Buddhist traditions due to the location of the Phra Boromaathad Nakhon Sri Thammarat temple (Kriangkraiphet 1997).

Nakhon Sri Thammarat is an ancient city with historical significance to the Thai economy, society, politics, governance, and religion. The origins of Nakhon Sri Thammarat date back to the $2^{\text {nd }}$ century AD, with archaeological evidence having been found in Sichon District, including archeological sites and artifacts pertaining to Hinduism. Examples can be found in bronze Buddha images crafted according to Amravati Indian traditions and Gupta Indian Buddhist arts. Between the $12^{\text {th }}$ century and the $14^{\text {th }}$ century AD, Nakhon Sri Thammarat reached its zenith under the rule of the Thamma Sokarat royal family. Immigrants from other lands sought refuge in the city due to the advantages offered by this land, which was a trading station on the peninsula. It is also where the holy remains of Lord Buddha are stored, making it a stronghold for faith and belief in Buddhism (Nakhon Sri Thammarat Office 2009).

At present, Nakhon Sri Thammarat comprises 23 districts. The most popular religions are Buddhism, Islam, and Christianity, respectively (Nakhon Sri Thammarat Office 2009). Its cultural heritage includes crafts made in the Nakhon Sri Thammarat style, which can be observed in Tambalinga style arts, an ancient art form that follows Dvaravati traditions that were influenced by Hinduism. Popular artistic styles can be found in the Phra Phutta Sihing arts, which were influenced by Langka (in present-day Malaysia) during the $14^{\text {th }}$ century to the $15^{\text {th }}$ century AD. Outside influences, especially from the central region of Thailand, have also contributed to the artistic style of Nakhon Sri Thammarat. These influences have blended with local folk art styles. For instance, the influence of the arts of the late Ayutthaya period led Nakhon Sri Thammarat to have the Buddha Pulling (Laak Phra or Chak Phra) festival during Buddhist Lent (Chumphengphan 2005, 143-155).

There are nine noteworthy festivities in Nakhon Sri Thammarat: (1) the Saat Duean Sib (Festival of the Tenth Lunar Month), which has roots in a Hindu ritual called Peta Phlee. It is a great ritual where descendants make merit to their deceased ancestors; (2) the Hae Phaa Khuen Phra Thaat (Tradition of the Procession) ritual, where Buddhists wrap up the stupa of Phra Boroma Thaat Woramahaa Wihaan Temple in the days of Makha Puja (Magha Puja Day is on the full moon day of the third lunar month in the last week of February or early in March) and Visakha Puja (Visakha Puja Day is on the 15th day of the waxing moon in the 6th lunar month.); (3) the Chak Phra or Laak Phra (Buddha Pulling) festival, held on Buddhist Lent when Buddha images are paraded both on land and water; (4) the Bathing of the Elderly festival, which is related to the Songkran festival; (5) the festival of prayer, where people make merit and listen to sermons in the temple during Buddhist holy days; (6) the Nang Daan 
procession, held annually on Mahasongkran Day ( $14^{\text {th }}$ April), which is part of a Hindu ritual called Triyampawai where the three Nang Daan goddesses are invoked to board palanquins and paraded to a designated spot, which is a Hindu temple; (7) the Kuan Khao Yaku custom, which is usually performed at temples by stirring Yaku rice on the $13^{\text {th }}$ and $14^{\text {th }}$ days of the waxing moon of April every year; (8) the Tak Baat Tuup Thien custom, where Buddhists offer incense, candles, and flowers to the holy remains of Lord Buddha at the stupa of Phra Boroma Thaat Woramahaa Wihaan Temple, with the candles and incense lit for worship at the beginning of the Buddhist Lent; and (9) the Fire Offering (the tradition of giving alms to the fire) festival, where a fire is lit for the monks on the temple patio so that they can tolerate the cold during dawn and at night when the temperature drops. . Besides offering warmth, Buddhists also give desserts to the monks. This festival occurs in January or February every year (Nakhon Sri Thammarat Office 2009).

\section{Intricate Paper Cutting Patterns, Techniques and Classification}

Prominent findings from studying primary sources include two categories of decorative patterns: 1) patterns that are conjoined to each other and 2) patterns that are non-conjoined, leaving only the background intact as the engraved patterns are removed. These two types of patterns are illustrated in Figures 2 to 5 , below. The left column shows the actual (original) patterns and the right column shows their two-dimensional representation (magnified for purposes of clarity).

As seen above, the features of the patterns are reflected in the choices of the master used in the indoctrination ceremony. However, the features of patterns used in intricate paper cuttings are believed also to be related to the locations and geographical features of the area.

In Songkhla, intricate paper cuttings can be found as decorations at all of these cultural events. Paper is cut into many patterns, such as Lai Thai, mythical creatures, and zodiac animals (Songkhla Cultural Office 2008). This technique is also found in many areas as coffin adornments, such as in Singhanakhon District, and as decorations at the funerals of villagers and monks. Popular patterns include Kranok and Bai Thet varieties whose unique detailed features reflect the conservation of traditional patterns since ancient times (Sa Thing Mo District Cultural Council n.d.). The techniques used in this cutting include boring through the paper and engraving the bored paper onto coloured paper. These techniques show the uniqueness of Songkhla artisans.

The festivals of Nakhon Sri Thammarat are numerous and varied and thus have resulted in the uniqueness of intricate paper cutting techniques. 
Original Graphic

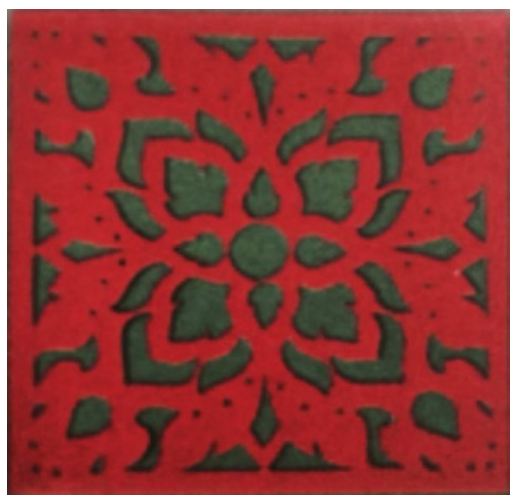

FIGURE 2 The Pracamyam Pattern (Conjoined) (Watthanaphu 2010)

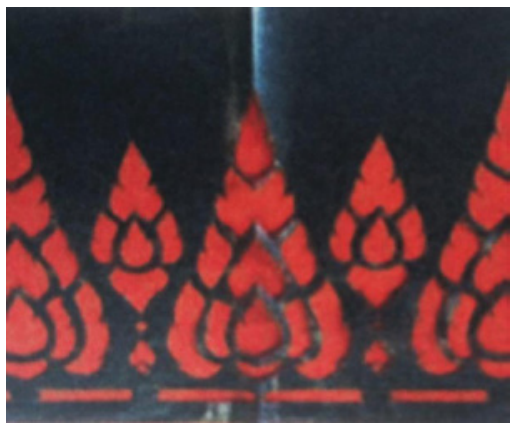

Figure 4 The Krui Choeng Pattern (Non-Conjoined) (Watthanaphu 2010)
Two Dimensional Graphic

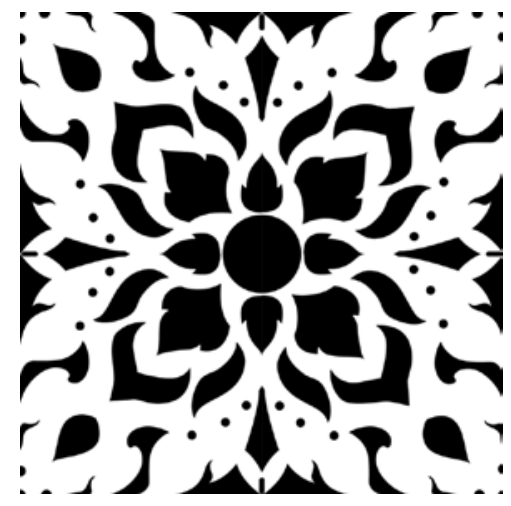

FIgURE 3 The Pracamyam Pattern (Conjoined)

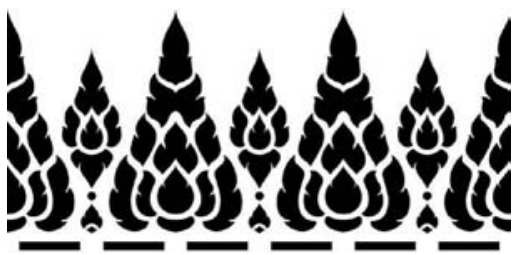

Figure 5 The Krui Choeng Pattern (Non-Conjoined)

The Buddha Pulling ritual requires intricate paper cutting techniques to decorate the Buddha Pulling vehicle. The decorations are highly regarded and therefore artisans put their skills into creating distinctively elegant patterns. These patterns differ from their Songkhla counterparts.

As for coffin decorations, the use of intricate paper cutting techniques is popular in the districts of Chulaphon, Ron Phiboon, and Cha Uad. People who are well-off prefer the use of gold coffins, a practice that has been observed since ancient times (Office of the National Culture Commission, Ministry of Culture 2006). Certain patterns used in intricate paper cuttings of the Nakhon Sri Thammarat style resemble those of the Songkhla style. Examples 
include the Pracamyam Lai Lukfak, Lai Khanap, Lai Bai Te Rin, and Lai Krui Choeng patterns. However, there are certain patterns of Songkhla artisans that are not used by their Nakhon Sri Thammarat counterparts, such as the Thep Phanom, ${ }^{5}$ Peek Khang Khaw (Bat wings), Thaw Lueay, and Rat Cha Wat patterns. The absence of these patterns serves to maintain their distinctive local identities. The paper cutting artisans of Nakhon Sri Thammarat utilise a technique of cutting through the foil first and then attaching papers of various colours, for example, orange, pink, and green, to create multiple shades. The shades used in their art are similar to the costume used in Manorah, a traditional performance art of Southern Thailand. (Virunanont 2015).

The following pictures present the Thai pattern of intricate paper cutting techniques from Songkhla and Nakhon Sri Thammarat provinces.

The techniques used include boring through the paper, engraving the bored paper onto coloured paper, and cutting through the foil and attaching coloured papers to create multiple shades. (See Figures 6-20)

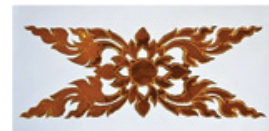

6: Lai Lukfak Kampu Bai Thet

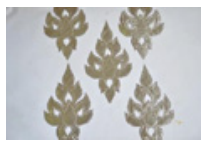

7: Lai Dok Loi

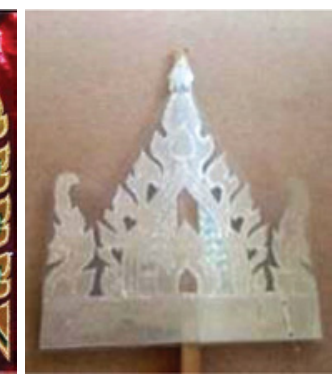

12: Lai Bai Te Rin
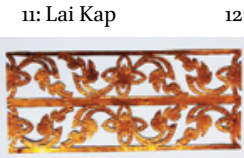

16: Lai Khanap

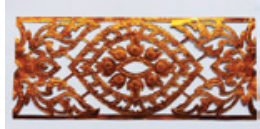

17: Lai Pracamyam Kampu

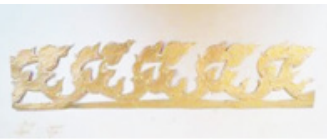

8: Lai Nongsing

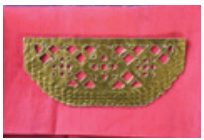

9: Lai Raya

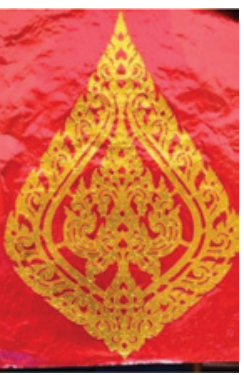

13: Lai Phum

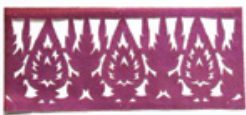

18: Lai Krui Choeng

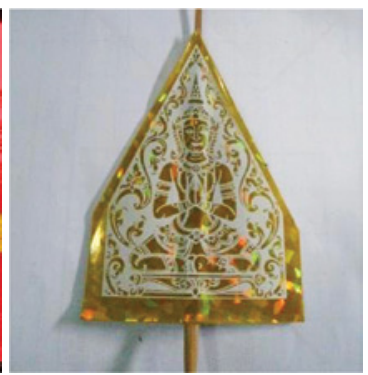

14: Lai Thep Phanom

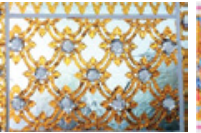

19: Lai Rat Cha Wat

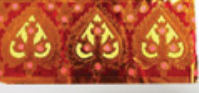

10: Lai Bua Khop

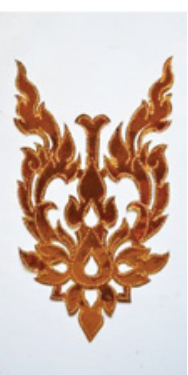

15: Lai Sao

FIGURES 6-20 Thai pattern of intricate paper cutting techniques from Songkhla and Nakhon Sri Thammarat Provinces (Virunanont 2015)

5 Thep Phanom is the figure of Deva clasping hands in token of worship. 
The data collection in the above section yielded three types of findings as follows:

\subsection{Thai Buddhist Beliefs, Culture and the Knowledge Transfer of Intricate Paper Artworks of Southern Thailand}

Traditional craftsmanship is a branch of sculptural creativity according to the categorization of the Ten Crafts of Thailand. It is an ancient art and valuable in terms of fine arts. This art is also known as Thai Traditional Art and displays culture and conventionality that is interlinked with beliefs. The local wisdom embedded in this art form is an abstract concept that consists of ideas, knowledge, beliefs, values, opinions, abilities, and intelligence (Thongdee 1999, 5-6). Belief is faith, respect, and credibility. The Thai Junior Encyclopedia Project (n.d.) states that religious faith that is shown in the daily life of a religious believer in the form of regulations or precepts can be named differently; for example, Buddhism has the Eightfold Path, Christianity the Ten Commandments, and Islam has rules to govern all things in life. Thai society does not differentiate between belief and religion. Buddhism discusses birth, old age, sickness, death, reincarnation, sins and merit, and donations as good deeds. This religious belief is intertwined with a belief in spirits and angels, ancestral worship, and the universe as well as the birth of humans and animals.

An example of the knowledge transfer of intricate paper artworks of Southern Thailand can be found in the belief of Khru Mo (Teacher). This belief is related to intricate paper cutting techniques used in decorating coffins. The artistic technique called the Kranok Long Thong Engraving Art is tied to the belief in life after death. The belief centres on the desire to let the deceased relative find happiness and be born in a better realm. Therefore, the ornate decoration of the coffin conveys the meaning that the living will also lead beautiful lives (Virunanont 2015).

The knowledge transfer of intricate paper cutting techniques of Southern Thailand is explained through beliefs in mysticism, which are firmly maintained by most artisans. They believe that once an apprentice has been enchanted or hexed by Khru Mo (Teacher) or Khru Mo Lai (Pattern Teacher), he or she will fall ill without reason. This sickness cannot be cured unless she or he takes an oath to inherit this artistic technique of intricate paper cutting. Upon swearing to inherit this art, the apprentice gets well and must take on this legacy. The next ritual is the teacher veneration ceremony, which all intricate paper cutting artisans must undergo before taking on the profession. The ceremony centres on respecting and having faith in masters. In this ceremony, 
the artisan venerates the Mae Lai (primary Lai Thai (Thai patterns)). These patterns are worshipped as masters of the artisan. The teacher recites incantations, inscribes ancient Khmer letters for self-protection, and casts magical spells to bring about mystical properties. Following that is the ritual of Indoctrination by Hand, where the Mae Lai (primary Lai Thai) is introduced to the disciple. An altar is erected and the ritual is performed annually. For intricate paper cutting techniques, the Khru Mo (Teacher) or Khru Mo Norah (Norah teacher), sometimes also known as Mo Taa Mo Yai (Elderly teacher), are subjects of veneration. This veneration ceremony is performed to show respect and gratitude to masters and is believed to bring about good fortune and prosperity to the artisan who filially performs it. The veneration is performed annually on the first Thursday of October. If any artisan fails to comply with this custom, it is believed that misfortune will befall them. Typical symptoms of misfortune include sickness and restlessness. The craft is passed on from the artisans to their family members and other willing apprentices through these rituals. Apprentices learn by absorbing the technique while helping the artisans. Each artisan will have only one apprentice at a time. There are five and four artisans in Songkhla and Nakhon Si Thammarat Province respectively. Therefore, there are about nine people who are learning this technique at this time (Virunanont 2015).

\subsection{Intricate Paper Cutting Techniques as Decorations for Auspicious Events}

Laak Phra (or Chak Phra) (Buddha Pulling) is an important festival that reflects the Thai-Buddhist culture of Southern Thailand. The Laak Phra (Chak Phra) Buddha Pulling festival of Southern Thailand has both terrestrial and aquatic versions. The terrestrial version is conducted by putting a Buddha image on a movable throne. The aquatic version of the festival is conducted on a boat. It is necessary to decorate the movable throne and the boat beautifully to show how much faith resides in the community, to reflect how people in that society lead their lives, and how community members support temple activities.

In the terrestrial version of Laak Phra (or Chak Phra) (Buddha Pulling), the gesture of the Buddha image is either the Um Baat pose (Alms Bowl Buddha posture) or Prathaan Aphai pose (Forgiving Buddha posture). The movable throne is placed on a wheel-less vehicle shaped like a boat or Naga. This vehicle is called Nom Phra (Phanom Phra) (The local language for Ruea Phra). The Nom Phra is pulled by designated groups of people andsometimes traditional dancing is performed in front of the vehicle. The reason this ritual is performed on land is because most temples are located quite a distance from rivers and canals. The aquatic version of the festival is conducted on a boat, which is 
named Ruea Phra (Buddha boat). On the boat, a Buddha image is put on the moveable throne. The pose of the Buddha can be in either the Um Baat or Prathaan Aphai gesture. The vehicle may consist of one or many boats; the latter is achieved by tying together many boats in the shape of a raft. The Mandapa, a square hall with a pyramidal roof, the pantheon, and the body of the boat are usually exquisitely decorated. Oarsmen are also hired to steer the boat during the procession. The rivers and canals are beautifully adorned. In addition, people will play music on the banks. This festival is so merry that it leads to various kinds of amusements, for example, Len Ruea Phleng (Folk Song), Prachan Pued (Taphoon) (two faced tabular drum competition), Prachan Phoon (Drum) (drum competition), and boat racing.

Figures 21 to 22 illustrate the intricate paper cutting techniques used to decorate the Laak Phra boat in Southern Thailand (Chumphengphan 2005). The Mandapa, pantheon, and body of the boat are usually exquisitely decorated. The examples in the figures portray the Phayanak and the Phum Song Khoabina patterns.

Laak Phra (Chak Phra) Festival organized by Songkhla Municipality holds two types of Buddha boat contest (Chak Phra Festival in Songkhla province where more than 30 temples submitted their decorated rafts to the design competition 2019) which are traditional and conservative. It has been found that most of the participating boats were traditional, decorated with foam and other brightly coloured materials, while there were fewer conservative boats and these were decorated with wood and natural materials that are local to the concept of building a boat with Thai designs and combined with home arts.

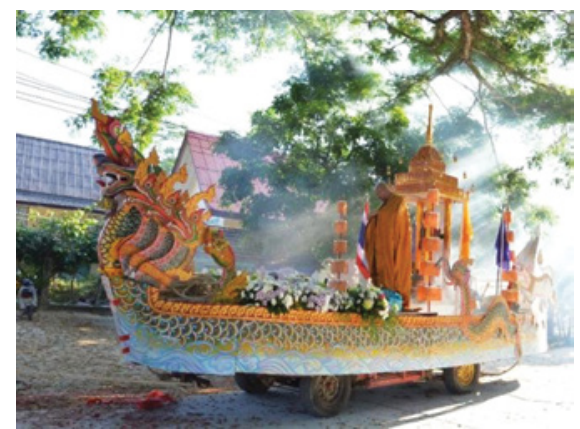

FIGURE 21 Wat Tah Kam's boat has a narrow boat head decorated with king of Nagas (Phuyanak) design Laak Phra (Chak Phra) festival, Songkhla Province. (Virunanont 2015)

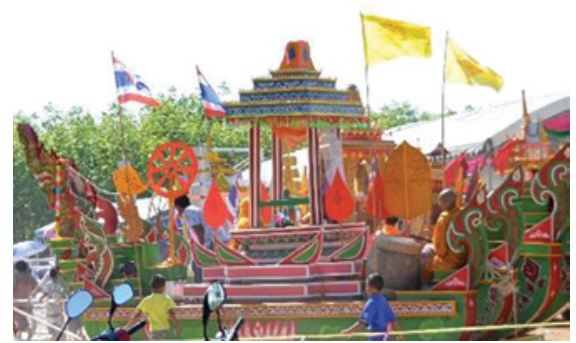

FIGURE 22 Wat Mae Toei's boat has the king of Nagas (Phuyanak) and Wheel of Dhamma design Laak Phra (Chak Phra) festival, Songkhla Province. (Virunanont 2015) 
Moreover, they also depict some sense of Buddhist morality. It takes over six months to produce the Buddha boat.

\subsection{Thai Buddhist Beliefs and Intricate Paper Cutting Techniques as Decorations for Coffins}

Rituals that relate to human death are associated with merit, sins, spirits, and life after death in both this and the afterworld. Therefore, the making of the coffin is another ritual that holds importance. In the past, Boeklong (Foremost ceremony), a ritual of placing the body into the coffin, was conducted after the completion of the coffin. This ritual contained various Dharma puzzles, such as the placing of the four beams that signify the crossing of the four mires: lust, rebirth, conviction, and ignorance. These beams are known as Maay Khaam Le (Ogha: the four floods is crossing the floods such as Kam Ogha, Ditti Ogha, Bhava Ogha and Avidya Ogha), and they represent the four that block the path to Nibbhana (Nirvana). There are also the seven strips of split bamboo, which are placed on three woven rope beams. The Dharma puzzle behind this is that the seven strips stand for the seven scriptures and the three rope beams refer to the Sutra, Vinaya, and Poramatta (three baskets of Buddhist scriptures). There is also the practice of not braiding the ropes back and forth as community members believe that the "back and forth" actions will cause the deceased to remain attached to the world of the living, which is undesirable (Khongmueanphet 1999, 20). Nowadays, the rite of Boeklong has nearly disappeared. Nonetheless, the placing of the seven beams still exists. Besides that, the relatives of the deceased still maintain the belief that the coffin is the last home of the dead person. The coffin, which is burnt during the cremation of the deceased, functions as a home in the afterworld.

Buddhists of Southern Thailand use temporary wooden coffins. Favoured decorations include gold and silver foil or coloured paper. The paper is engraved with delicate patterns and cremated with the dead (Culturalism 2008). In the past, coffins were made from wooden boards and the interior was insulated to prevent odour and liquids from ice or the body escaping. In former times, formaldehyde was not popularly used for preserving bodies. The standard practice was to put a large piece of ice inside the coffin. In some areas, honey was used to arrest decomposition. Coffins in Southern Thailand stand out from their northern counterparts in the base of the coffin, which is usually one of the two most popular types: Teen A Yong and Khrueang Chan. The first type looks like a tray, with the base spread out downwards and the mouth spread out upwards. A board called Phanak, measuring approximately 15 centimetres wide, is attached to the four sides. This Phanak is evenly spread out towards the corners. The centre of the base, which narrows down, is perpendicularly 
affixed to a flat board. This even board, called $E w$ (the waist), is surrounded by wooden triangles called $O k K a i$ at all corners. The entire base is about 80 to 100 centimetres high. The second type is a base from three to five layers high, where each layer gets narrower the higher up they go. Each layer is attached to flat boards. The lowest layer is made from a 30-centimetre-wide piece of wood. The width of the higher layers decreases gradually in a moderate style. The apex of the coffin is usually a tri-peak. The centre peak is roughly 20 centimetres taller than its lateral counterparts. Each peak has a square arched base. The pointed peak placed upon the coffin lid is called Yod Hem. This peak can be designed to have narrowing layers. The arches are sometimes made from boards or Rakam wood, depending on the area. The arches are roughly 60 centimetres high and made from lightweight wood. (see figures 23 to 27) They are designed to last and are not cremated with the dead (Nuthong 1999, 7037). At present, the coffin apex is reserved for the wealthy or prestigious. Ordinary people do not favour this item and prefer to decorate the coffin with flowers instead. As technology has advanced, cremation is now conducted in incinerators rather than on funeral pyres. Because of this, plywood coffins have become popular as they are economical and easy to produce.

Gold and silver foil papers are popular selections for coffin decorations among the artisans of Southern Thailand. They are engraved into Kranok patterns and are known as Daat Khud or Kradaat Khud (engraved bored paper). The decorations usually occur in the same row, which is the base. The coffin body is adorned with typical pale white paper, which is attached to all four sides. After that, the Daat Khud is attached to the body for beauty (Nuthong 1999, 7308). For common folk or the underprivileged, the decorations are limited to the body of the coffin. Gold paper with readymade patterns is usually the decoration of choice and may be coupled with Styrofoam cut into Lai Thai (Thai pattern). The name of the deceased, their age, date of birth, and date of death are also written on the coffin. The coffin is plainly designed, with no base or peak. On the other hand, coffins for respected seniors or the wealthy are

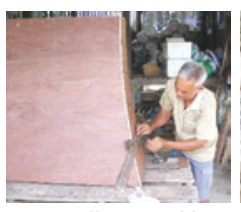

23: Coffin assembly

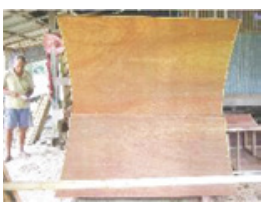

24: Wide side of wooden 24: Wooden coffin

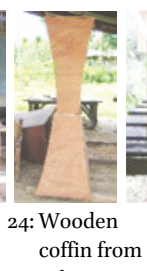

side view

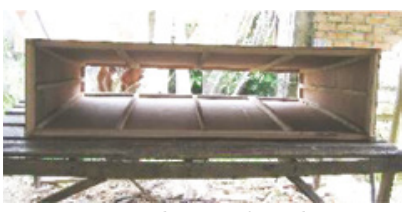

26: Inside view of wooden coffin

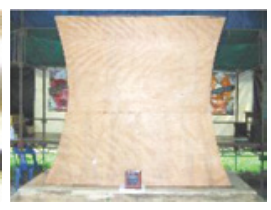

27: Wooden coffin ready for gold paper decoration

FIGURES 23-27 Coffin Assembly (Office of the National Culture Commission, Ministry of Culture 2006, 51) 
made with elegance and finesse. This type of coffin is called Long Thong and is used only for the specialty of the dead person. The traditional plywood is displaced by Kiri board and Formica plywood. However, the coffin is still exquisitely adorned with patterns of (1) Thep Phanom (the figure of deva clasping hands in token of worships), (2) angels (the illustrations of heavenly gods and goddesses), and (3) Lai Thai basic triangle shapes of Thai design. These designs were formerly made by modeling them into readymade embossed patterns. Nowadays, stickers have taken their place. These stickers come in various shades and are not limited to only white, black, blue or gold as in the past. In olden days, the artisan needed to be informed at least 15 days in advance so he could finish decorating a coffin. Among other things, the artisan had to prepare his work by going to the forest to cut and dry Rakam wood.

Before the artisan begins to work, he must venerate his masters. After the project is finished, the artisan has to pay respects to Khru Mo again in conjunction with the scattering of holy water onto the Kranok patterns. In the past, only four to five primary Lai Thai (Thai pattern) (Mae Lai) were used. These designs included the Lai Pracamyam Lukfak Kampo, Lai Fa Thuai (inverted and supine lotus flower), Lai Choeng Kracok, Lai Na Kradan, Lai Na Ut Rang Mum, and Lai Rong Kracok patterns. Later on, newer patterns were added to the artisan's inventory of primary designs. The decorative materials were exclusively gold and silver foil paper. Gloss paper made from Rakam wood was also used; the wood being honed and split before attaching it to glass. This gloss paper is called Luad Thaang Rakam. Nowadays, glinting paper has been added to the artisan's material list and foam sheets substitute for Rakam gloss paper. Nevertheless, some artisans of Nakhon Sri Thammarat still retain the use of traditional materials like Rakam wood. Other materials include Thong Phuen paper (gold sheet), which is used as a background base, Thong Kriab paper (gold engraved sheet), which is cut into Kranok patterns, and Sab Kradaat paper (inserted glowing sheet), which is coloured paper used to create multiple shades.

The making of gold coffins in Southern Thailand is reserved for senior or important people only. From interviews held with paper cutting artisans, it has been discovered that the decoration of the coffin with intricate paper cutting techniques reflect the spiritual and cultural beliefs of the local communities, which have been handed down for many generations (Virunanont 2015). Southern Thai artisans also state that, other than intricate paper cuttings, the coffins are decorated with three pagodas. This practice stems from the belief in the Sumeru (Phra Su Men) Mountain. ${ }^{6}$

6 The artisans described them as a symbol of the Buddhist belief that the souls are escorted to Daowadueng heaven, the second level where Indra dwells. This heaven has Phra Su Men 
The process of intricate paper cutting begins by drawing patterns on gold foil, which has been stacked in multiple layers. The next step is the cutting of the patterns with a sharp knife. This cutting process is called Khud Lai (engraved bored paper). Should the artisan desire to create joint patterns, he needs to utilize the mother-of-pearl inlay technique or perform a zigzag method on the gold foil which has undergone the Khud Lai process. The foil needs to be placed on background paper, which is glinting paper. The background is known as Thong Phuen (gold sheet) and is the place from which Lai Kranok patterns emerge. The outer frame (Krob Nok) is made from Thong Kriab paper and has dotted patterns on the borders. If the artisan wants to create multiple shades, he will shuffle together papers of various colours. Popular materials used for this purpose are coloured fluorescent paper, which reflects light well at night-time. Today, the Rakam wood has been replaced by coloured foam boards. In order to let viewers perceive the Kranok patterns in more volume and depth, glass is used as extra adornment. The use of glass results in a glittering and fluorescent effects. Other decorations, such as the Chat (tieredumbrella), the fan, the Chedi (stupa), and Sen (Bai KraJang Ruan) (Assembled pattern along the pattern border) are also utilised (Peekung n.d.). The Kranok decoration of the coffin or the making of Long Thong (gold coffin) is a folk handicraft categorised under woodwork and folk arts. This artistic technique of the Chulaphon district in Nakhon Sri Thammarat province is a unique piece of cultural heritage. This technique is reserved for respected seniors who have died of old age. It is a privilege enjoyed by the prestigious or wealthy (Tourism Authority of Thailand 2011). Examples of gold coffins are illustrated in Figures 28 to 31 , below:

Mountain, Su Mensu Mountain, and Satta Boriphan Mountain, according to Buddhist belief. After the interview with the artisans, more research was conducted on the topic of Buddhist belief and it was discovered that Phra Su Men Mountain, according to Brahmanism and Buddhism, is the core of the world located at the centre of the Earth or universe. It is the housing place for every soul of all universes such as demons, beasts, humans, Naga, Garuda, giants, davils, Gandharvas, hermits, and angels. At the mountain base, there is the Anon Fish circling. Phra Su Men Mountain is 1,344,00o kilometres above seawater (Phra Su Men Mountain is located over 84,00o tides of water), with another three mountains underneath (Phra Su Men Mountain, n.d.). Located at the top of Phra Su Men Mountain is Daowadueng heaven. There is a city of gods called Nakhon Trai Trueng where Lord Indra rules. He also governs earth, keeping virtue for all humans. Therefore, the three pagodas placed on the coffin are the representation of Phra Su Men Mountain where the angels are (Virunanont 2015), which is surrounded by three mountains. This belief has Hindu and Buddhist roots and states that the Sumeru Mountain is located at the centre of the world and universe and is where spirits in the world and other realms reside. At present, this inherited belief has diminished and supporting data is yet to be found concerning what happens when the coffin is not decorated with intricate paper cuttings. 
Gold coffin made by an artisan of Songkhla province

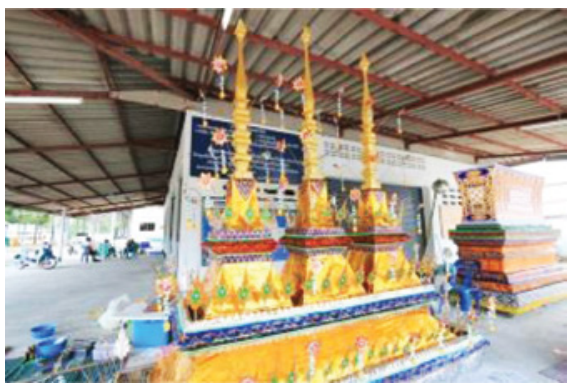

FIGURE 28 Artisan Name: Suan Nudla

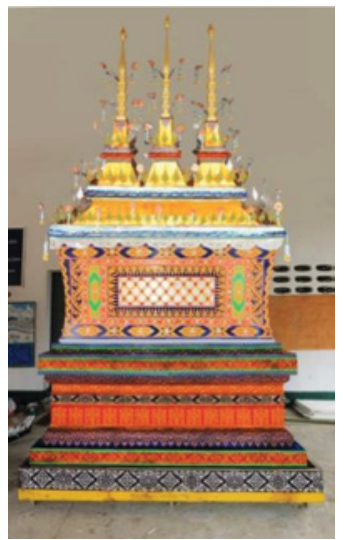

Gold coffin made by an artisan of Nakhon Sri Thammarat province

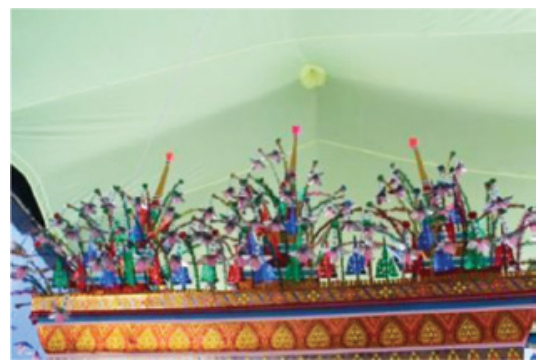

FIGURE 29 Artisan Name: Chalem Iadnimit

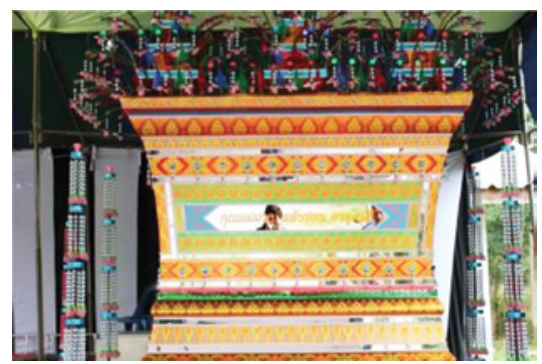

FIGURE 31 Artisan Name: Chalem Iadnimit

FIGURE 30 Artisan Name: Suan Nudla

Research findings reveal that the intricate paper cutting patterns of Southern Thailand are prominent because of their distinctiveness something that can be observed in funerary traditions. The colours used in the decoration of the coffin depend on the age of the deceased. A young person would merit in more colourful shades being used, such as red and green to depict liveliness. In contrast, an elderly or senior person would merit using gold colours to represent radiance and fertility. The use of black, blue, and white suggests longevity.

Interestingly, deceased elders merit the placing of triple pagoda coffins or Faa Haem, which stems from the belief in heaven. The coffins of deceased younger people do not have pagodas as their parents are still alive. A substitute for the pagoda is the Kranok Hua Khon (Ramayana mask pattern) or Paak Kluay (bowl-shaped). There is no lower base and a quadrapod (four-leg base) 
is used instead (Virunanont 2015). Examples of this type of intricate paper cutting technique can be found in Songkhla.

Another crucial point is that artisans follow the norm of using only one colour. If they use more than one, it is never more than three colours. The products are either exclusively gold or silver, or have shades of gold and red to reflect the individualism of the artisan (Virunanont 2015). These techniques differ from the same type of art found in Nakhon Sri Thammarat.

\section{$9 \quad$ Conclusion}

Intricate paper-cutting techniques of Southern Thailand are here deemed to be a form of folk art, first and foremost because the Southern Thai people and artisans who create them regard them as such. Also included in the consideration is the presence of eight aspects: (1) paper engraving techniques, (2) colours, (3) patterns, (4) instruments, (5) designs, (6) purpose of usage, (7) origins and history, and (8) methods of knowledge transfer. Most importantly, these techniques are distinctive in their own right and are linked to activities that reflect Buddhist beliefs. Nowadays, the function of these paper cutting arts is that they be used only with auspicious events and coffin decorations, but in a limited scope and manner. In the past, the paper was imported from Austria. Now, it is mostly ordered from China. However, parts of the foil are still bought from Austria. The primary design used in paper cutting is the Lai Lukfak Kampo or Lai Pracamyam Kampo pattern.

This technique is primarily concentrated in the areas of Songkhla and Nakhon Sri Thammarat provinces, while it is less common around the province of Trang and its neighbours like Phattalung province. The artistic identities of the patterns differ between the provinces of Songkhla and Nakhon Sri Thammarat. The design of the Lai Kranok Long or Lai Kranok Long Thong patterns adhere to traditional styles in Songkhla. In contrast, the Lai Thai (Thai pattern) of Nakhon Sri Thammarat focuses on creativity; the artistic identities of artisans are added to the traditional patterns. Examples can be found in the creation of Lai Thai (Thai pattern) and mother-of-pearl inlaying methods.

Southern Thai intricate paper cutting works of art have declined in the present day, due to the fact that the artistic work is costly and the same results can be achieved more cheaply by using stickers instead. Hence, it has been reduced to merely adornment of coffins belonging to prestigious people or respected family members. This artwork was formerly found at religious events as well but has now been replaced by stickers. Temple events, such as the Chak Phra or Laak Phra Buddha Pulling festival, prefer the printed silkscreen patterns of 
stickers to the original Lai Thai intricate patterns because these imitation stickers can be put to use quickly.

The transmission of the traditional paper-cutting as a form of folk art still exists as a "folk" transmission of knowledge. No instructional manuals have been written on how to prolong it. There is no mention of necessary materials and instruments used in producing intricate paper cutting arts. This art is inherited by the apprentice or helper, such as the son, the wife or close relatives as apprentices. Nonetheless, the inherited knowledge is not stable if the assistant is not constantly involved in the production process. He or she cannot remember or align the patterns and decorate them successfully. Therefore, I consider it is urgent and of great importance to compile an instructional manual that contains every detail of intricate paper cutting techniques in order to preserve this traditional art form.

\section{Acknowledgements}

This research was supported by the Department of Cultural Promotion, Ministry of Culture. I would like to thank Associate Professor Yothin Sawangdee, Ph.D., Institute for Population and Social Research, Mahidol University, Bangkok for comments that greatly improved the manuscript and Paweena Kulprasoot, Dhanyhaploy Nutkasem, Nutchanon Satanyasuwan and Areerat Sujirapanya for assistance with my research.

\section{References}

"Chak Phra Festival in Songkhla province where more than 30 temples submitted their decorated rafts to the design competition." 2019. Matichon Online. October 14, 2019. Retrieved from https://www.matichon.co.th/region/news_1711770. (In Thai)

Chantavanich, Supang. 2009. Qualitative Data Analysis. $9^{\text {th }}$ ed. Bangkok: Chulalongkorn University Press. (In Thai)

Charmaz, Kathy. 2006. Constructing Grounded Theory: A Practical Guide Through Qualitative Analysis. London: Sage.

Chumphengphan, Prathum. 2005. The Arts and Crafts of Southern Thailand. Bangkok: Sureewiriyasaat Press. (In Thai)

Culturalism. 2008. "The Coffin Seller: Business in the Afterworld." http://culturalism. blogspot.com/2008/10/blog-post_5377.html. (In Thai)

Department of Cultural Promotion, Ministry of Culture. 2014. Intellectual Cultural Heritage. Bangkok: Department of Cultural Promotion, Ministry of Culture. (In Thai) 
Glaser, Barney G. and Anselm L. Strauss., 2010. The Discovery of Grounded Theory: Strategies for Qualitative Research. $5^{\text {th }}$ ed. New Brunswick, NJ: Aldine Transaction.

Havanon, Napaporn, Pensiri Jeradechakul, and Surawut Pudthaisong. 2007. The Grounded Theory for Strengthened Community. Bangkok: The Thailand Research Fund. (In Thai)

Khongmueanphet, Klin. 1999. “The Mystery of Beliefs After Death.” Lae Taay Journal 68. (In Thai)

Kriangkraiphet, Somphong. 1997. A Diary of Southern Thai Culture. Bangkok: Dok Yaa Press. (In Thai)

Leesuwan, Wiboon. 200o. Folk Arts and Crafts. Bangkok: Ton Or 1999. (In Thai)

Nakhon Sri Thammarat Office. 20og. "The Origins and History of Nakhon Sri Thammarat Province." http://www.nakhonsithammarat.go.th/web_52/history.php. (In Thai)

Nakhon Sri Thammarat Province Cultural Office. 2006. Local Artisan Crafts: The Gold Coffin. Nakhon Sri Thammarat: Nakhon Sri Thammarat Province Cultural Office. (In Thai)

Nuthong, Udom. 1999. "Gold Coffins" Encyclopedia of Thai Culture: Southern Thailand, Book No: 14. Bangkok: Encyclopedia of Thai Culture Foundation, Siam Commercial Bank. (In Thai)

Office of the National Culture Commission, Ministry of Culture. 20o6. The Village, City, Knowledge Project on Local Products with Focus on Gold Coffin Local Arts. Bangkok: Ministry Press. (In Thai)

Peekung. n.d. "Cultural Heritage-Local Arts and Crafts and Products-Coffin Decorating Artisans of Trang Province.” Retrieved from http://www.iamtrang.com/detail_page .php?sub_id=483. (In Thai)

Phonphenphiphat, Chamaiphon. 2003. The Tung: A Heritage of Lanna (The Symbol of Good Fortune in the Northern Region). Bangkok: Daan Suttha Press.

"Phra Su Men Mountain." n.d. Retrieved from http://th.unionpedia.org/. (In Thai)

RakSutthi, Samlee. 2012. Succession of Isan Traditions, Religious Customs, and Legends. Bangkok: Pho So Phatthana. (In Thai)

Sa Thing Mo District Cultural Council. n.d. The Thai Cultural Project of Community Relationships: Collecting Local Intellectual Knowledge of Engraving Kranok Patterns on Coffins in Sa Thing Mo Sub-District of Singhanakhon District in Songkhla Province. Songkhla: Sa Thing Mo District Cultural Council. (In Thai)

Sarrattana, Wirot. 2013. "Grounded Theory Study." http://phd.mbuisc.ac.th/powerpoint/grounded.pdf. (In Thai)

Sirirak, Phaitoon. 2009. "The Nod-Naa-Le Way on the Sathing Phra Peninsula." http:// www.gotoknow.org/posts/437465. (In Thai)

Songkhla Cultural Office. 2008. The Contribution of Cultural and Communal Networks in Cultural Management and Administration: A Case Study of the Rab Thiam Daa 
Custom in Dee Luang Sub-District, Sathing Phra District, Songkhla Province. Songkhla: Songkhla Cultural Office. (In Thai)

Thai Jounior Encyclopedia Project. n.d. "Religious and Belief." http://saranukromthai .or.th/sub/book/book.php?book=2o\&chap=1\&page=t2o-1-infodetailo1.html. (In Thai)

"Thailand Map." n.d. Retrieved from http://thaiworld.5owebs.com/map.html. (In Thai)

"The Southern Region." 2004. Daily Manager Online. Retrieved from http://www .manager.co.th/Travel/ViewNews.aspx?NewsID=947000002579o. (In Thai)

Thongdee, Iam. 1999. Languages and Folk Cultures. Reference. Culture and Development Program, Research Institute for languages and cultures of Asia. Bangkok: Mahidol University. (In Thai)

Thuree, Somphon. 2016. "The Study of Thai Visual Arts in the Southern Region of Thailand." Journal of Fine Arts Research and Applied Arts 3 (1). Retrieved from http:// www.journal.rmutt.ac.th:8080/index.php/arts/article/view/551. (In Thai)

"Tourism Authority of Thailand." 2011. Retrieved from http://www.m-culture.in.th/ moc_new/album/111273/การทำโลงทอง. (In Thai)

Virunanont, Pannee. 2015. The Southern Thailand Intricate Paper Cutting Technique Research Project: Compiling and Collecting Data of Local Arts and Crafts as a Part of Traditional Works of Art and Intellectual Cultural Heritage (Songkhla and Nakhon Sri Thammarat Provinces). Bangkok: Department of Cultural Promotion, Ministry of Culture. (In Thai)

Watthanaphu, Narit. 2010. Pliu Lom Paintings: The Art of Paper Engraving. Bangkok: Boss Press. (In Thai) 